\title{
Emerging Joint Expertise? Multiagency Collaboration Described in Local Integration Programmes in Finland
}

SARI VANHANEN, University of Jyväskylä, Finland

\begin{abstract}
Multiagency collaboration is seen as an essential way of working to promote the two-way integration of newcomers and a receiving society. The term multiagency collaboration underlines the diversity of actors in cooperation. Cross-sectorial networks are mentioned in higher strategies as well as in the local programmes or plans for action. But how is multiagency work structured at the local level? This article looks at the examples of multiagency collaboration in the written documents of local integration programmes in the Finnish context. The examples are chosen from different areas. It seems that collaboration is widely emphasized as a goal or a working method. Whereas expertise in integration work is relatively novel in Finland, more analytical awareness of multiagency collaboration could support learning in networks and developing hybrid practices in this emerging field of knowledge.
\end{abstract}

Keywords: multiagency collaboration; two-way integration; local integration programmes; learning in networks; joint expertise

\section{Introduction}

This article investigates local integration programmes and the ways in which multiagency collaboration is mentioned in these documents. Here, the term multiagency collaboration highlights the diversity of actors in cooperation: not only the authorities or certain professionals, but also civil organizations, associations and ethnic or religious communities are represented. In essence, promoting the integration of migrants can be characterised as proactive work where the ideas of inclusion and emancipation are emphasised. Multiagency collaboration is justified in promoting active citizenship and participation of newcomers, and in developing good relations and fostering mutual interaction. Following the idea of two-way integration, the perspective and participation of immigrants in the multiagency collaboration is crucial as they are not only an object but partners and have an essential role in the cooperation. (Laki kotoutumisen edistämisestä 2010,3§)

On the other hand, collaboration can be a useful - and even necessary -method in 
formulating new knowledge and work processes (e.g. Isoherranen 2012; Palonen et al., 2014; Tynjälä 2008). In a novel field of expertise like promoting two-way integration in the Finnish society, both formal and informal learning are needed. According to Tynjälä (2008) learning in work can occur at different levels and learners may be individuals, groups, communities, organizations, networks and regions. Learning can be understood as the creation of new knowledge and considered a social process where the aim of participation is to develop new practices (Tynjälä 2008, 131).

It is notable that promoting, and even realising, integration services in the Finnish context is often based on project work and project based funding. Active networking is usually expected either in the project implementation and/or in project steering group with the representation of various actors. One specific project 'Osallisena Suomessa' (Participatory Integration in Finland) was mentioned in the Integration Act (2010) with the purpose of finding and creating local examples of good practices in promoting integration nationwide. The project targeted lifelong learning, starting from primary education of early years up to various forms of learning in adult education. The main outcome was the notion of the essential role of local collaboration and multiagency networks. Despite the demanding economic situation, new innovative work processes or working cultures were created, and they are expected to sustain. (Tarnanen et al. 2013; Osallisena Suomessa -hankkeen arviointiraportti 2013)

The purpose of the local integration programmes, based on the Integration Act in Finland (2010), is to coordinate and give guidelines to integration work at the local level. Programmes are compiled by a municipality or several municipalities together (Integration Act 2010, $6 \S$ and $31 \S-33 \S$ ). In practice, programmes can be seen as mediators between integration policy and everyday work at the local level. Before looking at the multiagency collaboration in the local integration programmes, a theoretical discussion related to the integration, multicultural policies and integration work 'dealing with dilemmas' at the street level are focused on from both a sociological and a multidisciplinary perspective (Hagelund 2008; Nordberg \& Wrede 2015). Yet the need for collaboration is connected with the changing demands in working life. Examples of local integration programmes are analysed by looking at how multiagency collaboration is mentioned and described. In the end, also the levels of learners in the integration work are reflected upon. This article can be seen as an opening for further discussion and analysis of local collaborative activities and the processes for emerging joint expertise in this specific field. 


\section{Multiagency collaboration in integration work: generating joint expertise?}

The issue of integration of immigrants revolves around the question of differences which includes identity discourses and recognising differences particularly in the public sphere (Pentikäinen 2008, 327; see also e.g. Alitolppa-Niitamo et al. 2012; Rastas et al. 2005; Martikainen et al. 2013; Saukkonen 2013). Parekh (2008) points out that the idea of integration is not as innocent as it seems. It involves a particular way of incorporating outsiders into the prevailing social structure, and it is sometimes either indistinguishable or only marginally different from assimilation. Immigrants might integrate at some of the levels (political, economic, social, moral and cultural) but not at others. Rather than ask how immigrants can be assimilated or integrated, we should ask how they can become equal citizens and be bound to the rest of the society by the ties of common belonging, which is a two-way process requiring a broad consensus on what is expected of each party (Parekh 2008, 85-87; see also Pentikäinen 2008; Brochmann \& Djuve 2013).

The process of integration is closely connected to multicultural policies, which from a sociological perspective can be viewed in two reciprocal ways: both as a form of claims-making by minority groups, and as a way in which the dominant society and its political system accommodate and manage diversity (Kivisto \& Wahlbeck 2013, 5). It is useful to break open the concept of multicultural policies in order to differentiate between measures targeted at ethno-cultural groups and policies where the goal is to transform common institutions in a manner that is more inclusive and hospitable towards ethnic diversity (Borevi 2012, 144-144).

How are these perspectives brought to practice? Welfare workers and institutions dealing with the dilemmas of integration at the street-level are both providing space for cultural diversity and promoting social equality. Public sector employees have created various repertoires to handle everyday dilemmas for which policies do not provide solutions (Hagelund 2009, 88-96). The dilemmas have also been touched upon from various perspectives in the Finnish context, in studies concerning e.g. interaction and interpretations in special issues and the definition of professional roles (Anis 2008); stress factors at work and training towards becoming critical pragmatic intercultural professionals (Brewis 2008); effects of cultural diversification in the work of civil servants (Hammar-Suutari 2009); intercultural competences of both the authorities and the immigrants (Lumio 2011); possible tensions between the authorities and the immigrants (Tanner 2008); school welfare personnel's and parents' views on the wellbeing of migrant children (Säävälä 2012); and emerging cultural diversity in Finnish youth work (Ahponen et al. 2014). Also the roles of immigrant, ethnic or religious associations have been analysed from a perspective of integration and as a part of modern governance and civil society (Pyykkönen 2007; Pyykkönen \& Martikainen 2012; Lautiola 2013).

Multiagency collaboration can be one method to settle dilemmas in daily work in the field of integration. According to McLaughlin et al. (2011) multi-professional col- 
laboration contains a shared understanding that a 'joined up' approach with 'joined up thinking' would reduce the overlap between services and promote the pooling together of expertise and resources, resulting in not only added value but a more effective and less costly service. The significance of collaboration is in being able to respond holistically to the needs of the service user, and to arrive at a more developed understanding of the problem and its potential solutions (McLaughlin 2011, 20; see also Isoherranen et al. 2008; Isoherranen 2012). However, the main challenges of developing inter-professional collaboration in an organisation have been seen in the roles involving agreed flexibility, the specification of responsibilities, the practices of developing shared knowledge, as well as in learning teamwork and interaction skills. Organisational structures constitute the fifth challenge as they do not always support the development of shared knowledge and a joint operating model (Isoherranen 2012, 6).

The multiplicity of domains is characteristic when thinking about the mechanisms for emerging expertise. Due to the complex and non-traditional nature of the problems to be solved, typical for many new areas of expertise, they are placed on the interface of traditional fields of expertise, infiltrating an entirely new area of research and knowledge production. Hybrid practices, processes and expertise enable lateral information flows and cooperation across the boundaries of organisations, firms and groups of experts or professionals (Palonen \& al. 2014, 136).

In sum, multifaceted processes of two-way integration and restructuring welfare state, different counterparts dealing with dilemmas at the local level and an option for new areas of expertise within various forms of lateral collaboration are combined at the local or street level. Following the definition of Kivisto and Wahlbeck, (2013), the dominant society shows various ways to accommodate and manage diversity e.g. through the local integration programmes. But what do the programmes say about multiagency collaboration: how is an active (or possible) dialogue mentioned and described?

\section{Research question and data}

As mentioned in the introduction, the aim of local integration programmes is to coordinate and give guidelines to integration work at the local level. The local programme is compiled by a municipality or several municipalities together. A municipality (or a coalition) has the responsibility to implement and develop the programme in collaboration with other actors. Furthermore it also has to follow the realisation of the programme and evaluate its impacts. The planning, implementation and development is completed by local authorities in co-operation with employment and economic development offices and other officials, and with organisations, associations and communities promoting integration and fostering good ethnic relations (Integration Act, 31-32§).

In this article I study local integration programmes from the perspective of multiagency collaboration asking a) how collaboration is mentioned and described, and b) what the forms for collaboration are. The material is based on three examples of local integra- 
tion programmes representing local variations and covering different parts of Finland.

It is notable that the integration programmes can vary between the municipalities because they are based on the independent service structure of each municipality. Another factor affecting local services is the number of immigrants that varies drastically between the municipalities in Finland, where the metropolitan area has the highest density of migrants but many rural municipalities may only have a few dozen. Most of the large cities have included the local integration programme in their wider strategic plans, yet some cities have also a separate immigration (also called 'multicultural') programme or a strategy. In the rural areas with aging and dwindling populations, either within one municipality or between several municipalities, local cooperation has an important role in developing and finding new options for services to sustain. (see e.g. Harilahti-Juola 2014; Mattila \& Björklund 2013)

The examples here are from a small city, a coalition of several municipalities and a large city. They are not painting the whole picture but offering some viewpoints for the questions above. Analysing the qualitative material in the form of written documents is based on content analysis (see e.g. Elo \& Kyngäs 2008).

\section{Collaboration described in three local integration programmes}

Examples of local integration programmes are from the city of Pudasjärvi, the region of Pietarsaari and the city of Tampere. All of them took part in the developing project 'Osallisena Suomessa' (Participatory Integration in Finland project) with different aims and focus groups. (Tarnanen et al. 2013)

The first example, the city of Pudasjärvi, is located at the edge of sparsely populated Lapland and has been facing strong socioeconomic challenges like many other regions in Northern and Eastern parts of Finland. Yet is has been a kind of innovator in developing local services to attract new residents with the slogan to combine an economy-based strategy with a wellbeing or 'vitality' strategy ( 'elinkeinopolitiikasta elinvoimapolitiikkaan'). One of Finland's reception centres for refugees is situated in Pudasjärvi. The City of Pudasjärvi has been actively developing the services for newcomers with the idea of including them within the general services that the municipality offers for all inhabitants. In addition, they have created new forms of services or ways of working to meet the needs of migrants, e.g. in attending and completing primary school in adulthood, and improving Finnish skills in new learning environments. (Harilahti-Juola 2014)

A network-based model in Pudasjärvi was built to coordinate the integration / migration work as part of the central administration in the municipality. This network is closely connected to services for education, employment, social and health, and leisure time services. The main task of the network is to have a holistic overview of the migration and to develop further services that are needed whatever the reason for immigration 
is. The main aim is to enhance the collaboration between the local actors (Pudasjärven kaupunki Kotouttamisohjelma 2013-2016, 7). Third sector organisations are involved as well, such as the Finnish Red Cross, the $4 \mathrm{H}$ club, Maa- ja kotitalousnaiset, MSL, sport clubs, parishes and village associations. They can receive special funding from the city for activities supporting two-way integration, the learning of the Finnish language and the building of positive ethnic relations (Kotouttamisohjelma, 21).

The second example represents the Swedish-speaking area on the western coast of Finland: the Pietarsaari region (including Pietarsaari, Uusikaarlepyy, Pedersöre, Luoto and Kruunupyy) has developed multiagency networks on a regional basis. Integration work is connected partly to an existing collaboration, and partly built up specifically in order to concretely share resources and tasks and promote joint knowledge (Pietarsaaren seudun kotouttamisohjelma 2014-2017, 5; 22-23; 44-45). It is notable that the number and profile of migrants varies in the region. The Oravainen/Oravais reception centre for refugees has locations in several municipalities.

In the integration programme of the Pietarsaari region a cross-sectorial collaboration between the authorities as well as with immigrants and local inhabitants is clearly emphasised. The programme clarifies the need for collaboration from three bases: multiagency collaboration between different actors (both authorities and associations), between various immigrant (or ethnic) communities as well as between local inhabitants and migrants. The aim is for all collaboration partners to have easy access to the information they need. They also mention the importance of having a joint contact person for updated information and interaction. In the city of Pietarsaari the cross-sectoral collaboration is active but further development is still needed. Also the learning institutions in the region have regular meetings concerning the needs arising from the immigrant population. It is mentioned that for example in preparatory teaching (valmistava opetus) for newcomers there is a need for sharing experiences, finding regional solutions and maintaining cooperation. Additionally, the collaboration between the municipalities is emphasised in the various services for receiving refugees. According to the regional integration programme, the collaboration should attain all the sectors more permanently and this should be coordinated persistently. A joint organ with decision-making powers provides a comprehensive follow-up and evaluation of the programme. (Pietarsaaren seudun kotouttamisohjelma 2014-2017)

The third example, the city of Tampere in the Pirkanmaa region, has profiled itself with a strong emphasis on the active role for newcomers and a vivid interaction between all inhabitants. In Tampere migration is characterised by a high percentage of international students and specialists at the local universities. The integration programme of Tampere claims that client-oriented integration is based on the functional collaboration between different sectors of administration. Regular meetings and active discussions are organised in order to sustain and develop cross-sectorial collaboration. The unit managers of the different municipal sectors are supposed to offer reasonable time resources for their staff to participate in cross-sectorial networking. In the meetings new sugges- 
tions are given to better and more efficiently organise integration work. Cross-sectorial cooperation is also seen as a tool for diminishing costs.

Furthermore, the integration programme of Tampere emphasises an active partnership with the private and the third sector, the local education institutions and a larger regional network and there are regular cross-sectorial meetings to promote this partnership. The third sector organisations, including immigrant associations, are encouraged to produce services to promote integration. The aim is to encourage long term partnerships in ordering these services. The third sector is very active, with services and integration activities available for immigrants. There are several associations and projects developing further activities, including the Finnish Refugee Council's Organization Incubator (Järjestöhautomo) project that supports immigrant associations. The Tampere Immigrant Council has been established in an advisory capacity but it lacks decision-making powers (Tampereen kaupungin kotouttamisohjelma 2010-2020). The city of Tampere is also part of the EUROCITIES network of good practices in integration.

\section{Conclusions for further discussion}

The Integration Act in Finland requires local multiagency collaboration to be initiated by a municipality. The relevance of joint networks and multiagency collaboration in promoting two-way integration at the local level can be found in local integration programmes. Although the forms of collaboration can vary according to local context and specific characteristics, an active cross-sectorial work is emphasised.

How is collaboration mentioned and described? Because the municipalities are the key-unit in undertaking the integration programme, the collaboration is closely connected to the service structure in each municipality and the authorities involved. When the programme is shared by a coalition of municipalities, an active networking between the partners is a prerequisite for collaboration. In all the example programmes in this material, collaboration is described as cross-sectorial work. For example, in Tampere the unit managers are supposed to offer reasonable time resources for the joint network, and in Pudasjärvi cross-sectorial collaboration is seen as a platform for the integration programme to be implemented. On the other hand, collaboration is connected to the inclusion or partnership of newcomers. An active interaction between all inhabitants is supported in neighbourhoods or in low-threshold activities (culture or sport clubs). Furthermore, the collaboration with third sector organisations and/or migrant associations is mentioned in integration programmes with local variations.

What are the forms for collaboration? In the programmes based on the coalition of municipalities there are many forms for collaboration: not only a joint advisory committee but also e.g. in language education and in the use of interpreters collaboration is seen important. In addition to the authorities, multiagency collaboration includes e.g. third sector and local parishes of different religions. Collaboration with the migrant associations has various forms. One of these is encouraging and informing the asso- 
ciations to provide services for the municipality. Regional, national and international networks are one further form in collaboration. These are necessary in developing the local integration work in general but also getting project based funding for new activities. However, the coordination of the multiagency collaboration is seen as significant.

Thinking about the levels of learning (Tynjälä 2008), who are the learners in multiagency collaboration connected to integration work? In the local integration programmes, the need for promoting new knowledge and work practices is mentioned in different ways. Here, the learners are individuals, organisations and regions. The need for knowledge creation in the integration work is emphasised. According to this material it seems that the authorities are expected to share and fulfil their expertise with the colleagues both with similar professional background and also with other experts, actors or institutions. Not only the newcomers but also the neighbourhoods are supposed to learn reciprocally.

A remarkable character in the local integration programme is dealing with a timespan. In restructuring the welfare state alongside multifaceted processes of two-way integration, one aim is to build up persistent work practices, as stated in the programmes above. It is noted that the measures and practices should be available to all immigrants as a part of the general basic advisory service provided to all local residents. Yet the local integration programmes are to be checked every four years following the time period of municipal elections. This may cause critical evaluation e.g. of the assets at the local level. As mentioned earlier, the integration practices are often based on temporary project work and funding. So the local integration programmes are dealing both with continuance and transformation according to the political atmosphere and project phases. Multiagency collaboration is connected to a similar play with permanent practices and discontinuities where some actors have a more stable status than the others.

However, the main challenges in collaboration (Isoherranen 2012) concern the roles involving agreed flexibility and the specification of responsibilities. In the examples of local integration programmes the organisational structures for multiagency work are described but there is a need for analysing how well or poorly these structures support the development of shared knowledge and joint expertise in the field of two-way integration. In the future there is a need to more closely analyse the multiagency collaboration from this point of view. Nevertheless, this article offers one perspective on the question about how a dominant society and its political system accommodate and manage diversity (Kivisto \& Wahlbeck 2012), or how common institutions transform to become more inclusive towards ethnic diversity (Borevi 2012). Later on it will be important to look more closely at the functions of collaboration and also at the significances of expanding expertise. 


\section{References}

Ahponen, P., Harinen, P., Honkasalo,V., Kivijärvi, A., Pyykkönen, M., Ronkainen, J., Souto, A-M. \& Suurpää, L. (2014) New challenges for Nordic welfare services. Emerging Cultural Diversity in Finnish Youth Work. Nordic Journal of Migration Research. Volume 4, Issue 1, pp. 30-39.

Alitolppa-Niitamo, A., Fågel, S. \& Säävälä, M. (Eds.) (2013). Olemme muuttaneet-ja kotoudumme. Maahan muuttaneen kohtaaminen ammatillisessa työssä. [We Have Migrated - and Feel Home Here. Professionals Meeting with Immigrants at Their Work.] Väestöliiton Monikulttuurinen osaamiskeskus. Kirjapaino Fram, Vaasa.

Anis, M. (2008). Sosiaalityö ja maahanmuuttajat. Lastensuojelun ammattilaisten ja asiakkaiden vuorovaikutus ja tulkinnat. [Social Work and Immigrants. Interaction and Interpretations of Child Protection Professionals and Clients ] Väestöntutkimuslaitoksen julkaisusarja D 47/2008, Helsinki.

Borevi, K. (2013) Understanding Swedish Multiculturalism. In Kivisto, P. \& Wahlbeck, Ö. (Eds.) Debating Multiculturalism in the Nordic Welfare States. pp. 219-45. Palgrave Politics of Identity and Citizenship Series. Palgrave Macmillan, pp. 140-69.

Brewis, K. (2008) Stress in the Multi-ethnic Custormer Contacts of the Finnish Civil Servants. Developing Critical Pragmatic Intercultural Professionals. Jyväskylä Studies in Humanities 103. University of Jyväskylä.

Brochmann, G. \& Djuve, A. (2013). Multiculturalism or Assimilation? The Norvegian Welfare State Approach. In Kivisto, P. \& Wahlbeck, Ö. (Eds.) Debating Multiculturalism in the Nordic Welfare States. pp. 219-45. Palgrave Politics of Identity and Citizenship Series. Palgrave Macmillan.

Elo, S. \& Kyngäs, H. (2008). The Qualitative Content Analysis Process. Journal of Advanced Nursing 62(1), pp. 107-115.

Hagelund, A. (2009). Dealing with the Dilemmas: Integration at the Street-level in Norway. International Migration. Volume 48 (2), pp. 79-102.

Hammar-Suutari, S. (2009) Asiakkaana erilaisuus - Kulttuurien välisen viranomaistoiminnan ethnografia. [Difference as a Client - Ethnography of Intercultural Civil Servats.] Publications of Carelian Institute n:o 147. University of Joensuu.

Harilahti-Juola, V. (2014). Maahanmuutto tuo kuntaan uusia kuntalaisia. [Migration Brings New Residents to a Municipality]. In Heikkilä, E. (Ed.) Haavoittuvasta lapsuudesta ehjään aikuisuuteen. Siirtolaisuusinstituutti, Tutkimuksia A 49. Pallosalama, Turku.

Isoherranen, K., Rekola. L. \& Nurminen, R. (Eds.) (2008) Enemmän yhdessä. Moniammatillinen yhteistyö. [Together More. Multiprofessional collaboration]. Sanoma Pro Oy.

Isoherranen, K. (2012). Uhka vai mahdollisuus - moniammatillista yhteistyötä kehittämässä. [Threat or opportunity. Promoting interprofessional collaboration.] Helsingin yliopisto, Sosiaalitieteiden laitos. Sosiaalitieteiden laitoksen julkaisuja 2012:18

Kivisto, P. \& Wahlbeck. Ö. (Eds.) (2013). Debating Multiculturalism in the Nordic Welfare States. Palgrave Politics of Identity and Citizenship Series. Palgrave Macmillan.

Laki kotoutumisen edistämisestä (1386/2010), [Integration Act in Finland] http://www.finlex.fi/fi/ laki/ajantasa/2010/20101386 [assessed 7 September 2014]

Lautiola, H. (2013) Kumppanuutta kotouttamisen kentillä. Esimerkkejä järjestöjen ja viranomaisten yhteistyöstä kotouttamisessa. [Partnership in the Fields of Integration. Examples of Collaboration Between Assiociations and Authorities]. Suomen kulttuurirahasto, Kopio Niini.

Lumio, M. (2011) Hymyn takana - Thaimaalaiset maahanmuuttajat, viranomaiset ja kotoutuminen. [Behind the Smile. Thai Immigrants, Authorities and Integration] Poliisiammattikorkeakoulun raportteja 93. Poliisiammattikorkeakoulu. Tampereen yliopistopaino Oy, Juvenes Print.

Martikainen, T., Saukkonen, P, \& Säävälä, M. (Eds.) (2013). Muuttajat. Kansainvälinen muuttoliike ja suomalainen yhteiskunta. [Migrants. International Migration and a Finnish Society]. Gaudeamus. 
Mattila, M. \& Björklund, K. (2013). Tomaatteja, teollisuutta ja monikulttuurisuutta. Närpiön malli maahanmuuttajien kotouttamisessa. [Tomatoes, Industry and Multiculturalism. A model of Närpiö in Integration of Immigrants.] Aluekeskuksen tutkimuksia nro 5. Siirtolaisuusinstituutti, Turku.

McLaughlin, H., Reubsaet, H. \& Vanhanen, S. (2011). Introduction. In Heikkilä, E., Danker, M., Cómez Ciriano, E., McLaughlin, H. \& Reubsaet, H. (Eds.) Working Together for Better Integration - Immigrants, Police and Social Work. pp. 7-22. Migration Studies C18. Institute of Migration, Turku. Nordberg, C. \& Wrede, S. (2015) Street-Level Engagements: Migrated Families Encountering the Local Welfare State. Nordic Journal of Migration Research. 5(2), pp. 54-57.

Osallisena Suomessa -hankkeen arviointiraportti (2013) [The Evaluation Report of Participatory Integration in Finland -project]. Työ- ja elinkeinoministeriön julkaisuja. Konserni 29/2013.

Palonen, T., Henry P.A. Boshuizen, H.P.A. \& Lehtinen, E. (2014). How Expertice is Created in Emerging Professional Fields. In Halttunen, T., Koivisto M. \& Billett, S. (Eds.) Promoting, Assessing, Recognizing and Certifying Lifelong Learning. pp. 131-149. International Perspectives and Practices. Springer, Dordrecht.

Parekh, B. (2008). New Politics of Identity. Political Principles for an Interdependent World. Palgrave Macmillan.

Pentikäinen, M. (2008) Creating an Integrating Society and Recognizing Differences. The Role and Limits of Human Rights, with Special Reference to Europe. Acta Electronica Universitatis Lapponiensis 38 .

Pyykkönen, M. (2007). Järjestäytyvät diasporat. Etnisyys, kansalaisuus, integraatio ja hallinta maahanmuuttajien yhdistystoiminnassa.[Organised Diasporas. Ethnicity, Citizenship, Integration and Governance in Migrant Associations]. Jyväskylä Studies in Education, Psychology and Social Research. Jyväskylän yliopisto.

Pyykkönen, M. \& Martikainen, T. (2013). Muuttoliike ja kansalaisyhteiskunta. [Migration and Civil Society]. In Martikainen, T., Saukkonen, P. \& Säävälä, M. (Eds.) Muuttajat. Kansainvälinen muuttoliike ja suomalainen yhteiskunta. pp. 281-300. Gaudeamus.

Rastas, A., Huttunen, L. \& Löytty, O. (Eds.) (2005). Suomalainen vieraskirja. Kuinka käsitellä monikulttuurisuutta. [A Finnish guestbook. How to Handle Multiculturalism]. Vastapaino, Tampere.

Saukkonen, P. (2013) Erilaisuuksien Suomi. Vähemmistö- ja kotouttamispolitiikan vaihtoehdot. [Finland and Differences. Alternatives of Minority and Integration Policy]. Gaudeamus.

Säävälä, M. (2012) The Burden of Difference? School Welfare Personnel's and Parents' Views of Wellbeing of Migrant Children in Finland. Finnish Yearbook of Population Research 2012, pp. 31-50.

Tanner, A. (2008). Poliisi ja maahanmuuttajat. Kohti kotoutumista edistävää vuorovaikutusta. [Police and Immigrants. Towards the Interaction Promoting Integration]. Poliisiammattikorkeakoulun raportteja 67. Tampere.

Tarnanen, M., Pöyhänen, S., Lappalainen M. \& Haavisto, S. (Eds.) (2013). Osallisena Suomessa. Kokeiluhankkeiden satoa. Delaktig i Finland. Skörden från försöksprojekten.[Participatory Integration in Finland. Findings from the Pilot Projects]. Jyväskylän yliopisto, Soveltavan kielentutkimuksen keskus. Suomen Kulttuurirahasto. Svenska kulturfonden. Jyväskylä \& Helsinki/Helsingfors.

Tynjälä, Päivi (2008) Perspectives into Learning at the Workplace. Educational Research Review. Vol. 3 (2), pp. 130-154 


\section{Local integration programmes:}

Pietarsaaren seudun kotouttamisohjelma 2014-2017. [Integration Programme of Pietarsaari Region] http://www.kotouttaminen.fi/files/41552/Pietarsaaren_seudun_kotouttamisohjelma_2014-2017.pdf

Pudasjärven kaupunki. Kotouttamisohjelma 2013-2016. [Integration Programme of City of Pudasjärvi] http:/www.pudasjarvi.fi/images/liitteet/maahanmuuttajat/kotouttamisohjelma_2013-2016.pdf

Tampereen kaupungin kotouttamisohjelma 2010 - 2020. Tampere virtaa: Sujuvan kotouttamisen vastuullinen kaupunki.[Integration Programme of City of Tampere. Tampere Flows: A Responsible City of Fluent Integration] http://www.tampere.fi/material/attachments/k/unnamed_6421/ koto_ohjelma2010.pdf 
